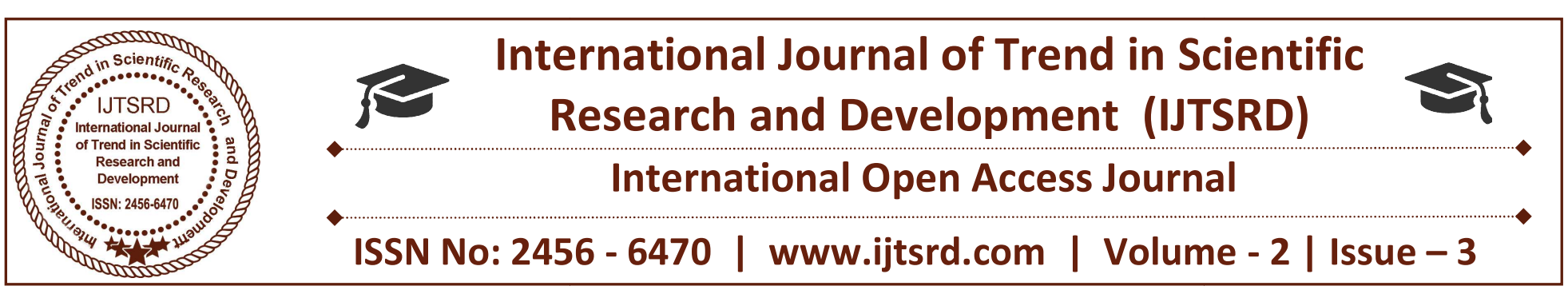

\title{
Heat Transfer Augmentation in Heat Exchanger using Nanofluid: A Review
}

\author{
Shriram Pathak \\ Research Scholar, Department of Mechanical \\ Engineering, Millennium institute of Technology, \\ Bhopal, Madhya Pradesh, India
}

\author{
Amit Kaimkuriya \\ Asst. Professor, Department of Mechanical \\ Engineering, Millennium institute of Technology, \\ Bhopal, Madhya Pradesh, India
}

\section{ABSTRACT}

Due to the limitation of fossil fuels, shortage of energy, optimization of energy consumption in various industrial processes becomes very important and challenging issue all over the world. A reduction in energy consumption is possible by enhancing the performance of heat exchanger and it is one of the most important devices related to energy and heat transfer. Nano fluid is a new engineering fluid which could improve the performance of heat exchanger. Nano fluids have greater potential for heat transfer enhancement and highly suited to application in practical heat transfer processes. Heat exchanger using Nano fluid is a device in which the heat transfer takes place by using Nano fluid. Nano fluid is made by the suspending Nano particles in the fluid like water, ethylene glycol and oil, hydrocarbons, fluorocarbons etc. The main focus of this paper is to determine the possibility and future scope of Nano fluids in the terms of heat transfer augmentation. This review covers the enhancement of heat transfer by using Nano fluids and potential applications of Nano fluids. This paper presents an updated review of the heat transfer applications of Nano fluids to develop directions for future work because the literature in this area is spread over a wide range of disciplines, including heat transfer, material science, physics, chemical engineering and synthetic chemistry.

Keywords: Nano fluids, Heat Exchanger, Thermal Performance Factor.

\section{INTRODUCTION}

India is blessed with an abundance of sunlight, water and biomass. Vigorous efforts during the past two decades are now bearing fruit as people in all works of life are more aware of the benefits of renewable energy, especially decentralized energy where required in villages and in urban or semi-urban centers. India has the world's largest programmed for renewable energy. Government created the Department of Non-conventional Energy Sources (DNES) in 1982.

Energy is defined as the ability or the capacity to do work. Energy is the basic ingredient to sustain life and development. Work means moving or lifting something, warming or lighting something. There are many sources of energy that help to run the various machines invented by man. There has been an enormous increase in the demand for energy since the middle of the last century as a result of industrial development and population growth. World population grew 3.2 times between 1850 and 1970, per capita use of industrial energy increased about twenty fold, and total world use of industrial and traditional energy forms combined increased more than twelve fold. Nano fluid, a suspension of Nano particles in a continuous and saturated liquid, has been found capable to get considerably higher thermal conductivities than their respective base fluids resulting in better convective heat transfer coefficients. Fluids have higher specific heat compare to metals, and metals have higher thermal conductivity compare to solids. So when we added a small amount of Nano particle to base fluid it will increase the thermal conductivity of base fluid. 
Nano fluids have attracted much attention recently because of their potential as high performance heat transfer fluids in electronic cooling and automotive. Performance of heat transfer equipment can be improved with studies related to a significant increase in heat flux and miniaturization. In many industrial applications such as power generation, microelectronics, heating processes, cooling processes and chemical processes, water, mineral oil and ethylene glycol are used as heat transfer fluid.

\section{PREPARATION NANOFLUID}

METHODS FOR

Nano fluids are a new class of fluids engineered by dispersing nanometer-sized materials (nanoparticles, nanofibers, nanotubes, nanowires, nanorods, nanosheet, or droplets) in base fluids. In other words, nanofluids are nanoscale colloidal suspensions containing condensed nanomaterials. They are twophase systems with one phase (solid phase) in another (liquid phase). Nanofluids have been found to possess enhanced thermophysical properties such as thermal conductivity, thermal diffusivity, viscosity, and convective heat transfer coefficients compared to those of base fluids like oil or water. It has demonstrated great potential applications in many fields.

For a two-phase system, there are some important issues we have to face. One of the most important issues is the stability of nanofluids, and it remains a big challenge to achieve desired stability of nanofluids. In this paper, we will review the new progress in the methods for preparing stable nanofluids and summarize the stability mechanisms.

\subsubsection{Two-Step Method}

Nanofluid for the experiment was prepared in nano technology lab in physics department at MANIT Bhopal. Two-step method is the most widely used method for preparing nanofluids. Nanoparticles, nanofibers, nanotubes, or other nanomaterials used in this method are first produced as dry powders by chemical or physical methods. Then, the nanosized powder will be dispersed into a fluid in the second processing step with the help of intensive magnetic force agitation, ultrasonic agitation, high-shear mixing, homogenizing, and ball milling. Two-step method is the most economic method to produce nanofluids in large scale, because nanopowder synthesis techniques have already been scaled up to industrial production levels. Due to the high surface area and surface activity, nanoparticles have the tendency to aggregate. The important technique to enhance the stability of nanoparticles in fluids is the use of surfactants. However, the functionality of the surfactants under high temperature is also a big concern, especially for high-temperature applications.

In this method, the nanoparticles are directly mixed in the base liquid and thoroughly stirred. Nano fluids prepared in this method give poor suspension stability, because the nanoparticles settle down due to gravity, after a few minutes of Nano fluid preparation. The time of particle settlement depends on the type of nanoparticles used, density and viscosity properties of the host fluids.

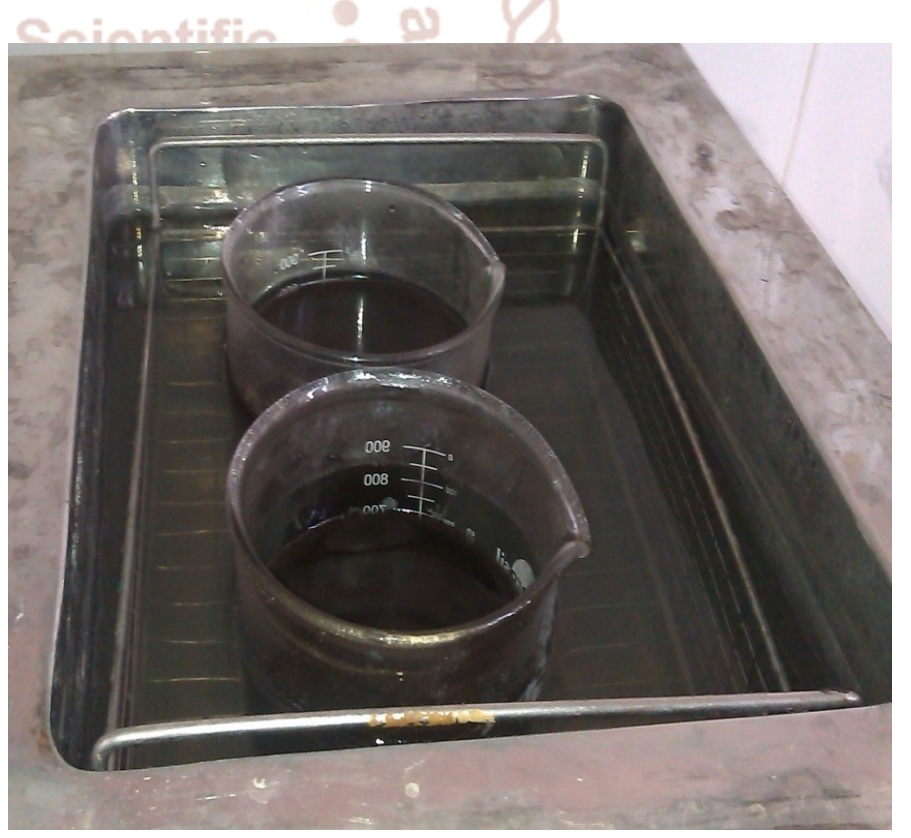

Fig. 1 Ultrasonic Cleaner apparatus for sonication process of Nano fluids 


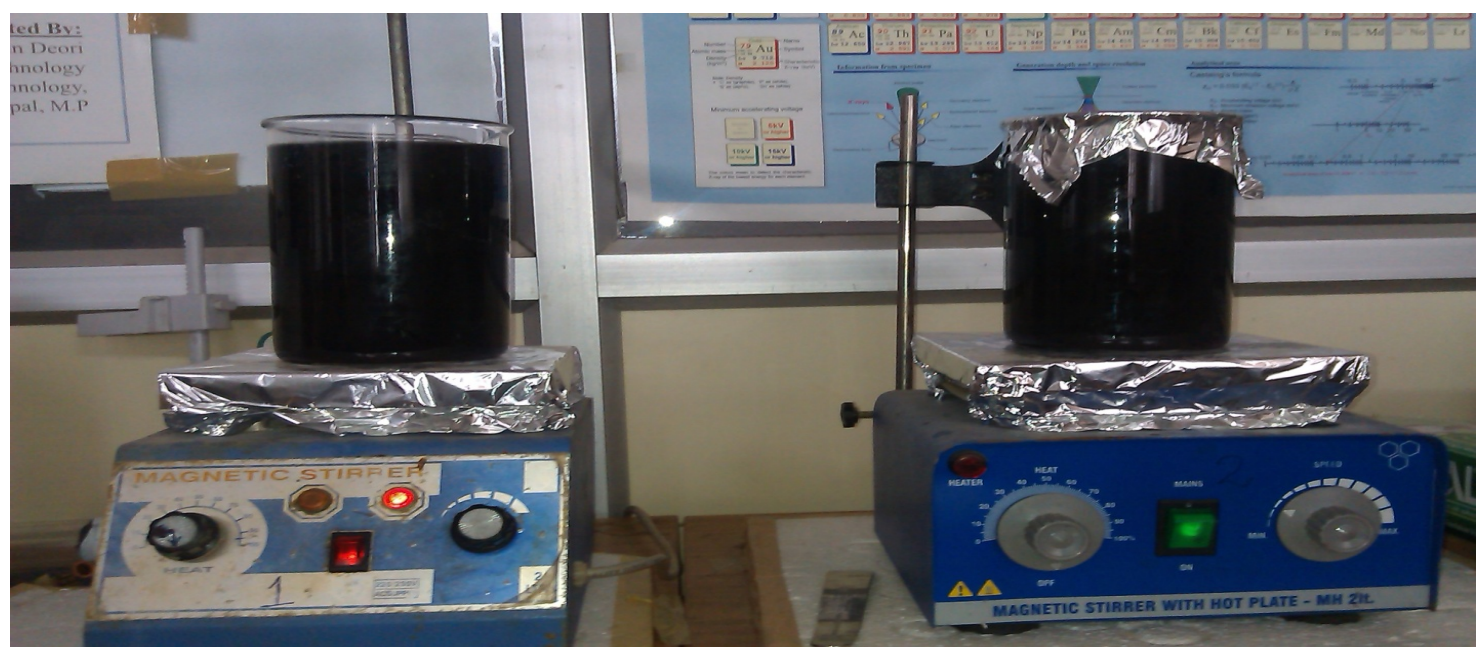

Fig. 2 magnetic stirring of sonicated mixture

III LITERATURE REVIEW

\begin{tabular}{|c|c|c|c|c|}
\hline Author & Parameter & $\begin{array}{l}\text { Type of } \\
\text { nanofluid }\end{array}$ & $\begin{array}{l}\text { Type of } \\
\text { insert/Heat } \\
\text { Exchanger. }\end{array}$ & Result \\
\hline $\begin{array}{l}\text { Khwanchit } \\
\text { Wongcharee et } \\
\text { al. } \\
2011\end{array}$ & $\begin{array}{l}\text { twist ratios of } \\
\text { twisted tape: } \\
y / w=2.7,3.6 \text { and } \\
5.3, \\
\text { Re No. } 6200 \text { to } \\
24000 \text {,Inner tube- } \\
\text { corrugated }\end{array}$ & $\begin{array}{l}\mathrm{CuO} / \text { water, } \\
\mathrm{CuO} \\
\text { concentrations: } \\
0.3,0.5 \text { and } \\
0.7 \% \text { by } \\
\text { volume in }\end{array}$ & $\begin{array}{l}\text { Journal } \\
\text { bientific }\end{array}$ & $\begin{array}{l}\text { Heat } \\
\text { transfer rate and friction } \\
\text { factor increase to } 2.67 \text { times } \\
\text { and } 5.76 \text { times of those in } \\
\text { the plain corrugated tube. }\end{array}$ \\
\hline $\begin{array}{l}\text { A.E. Kabeel et } \\
\text { al.2012 }\end{array}$ & $\begin{array}{l}\text { Re No. }-1000 \text { to } \\
2400\end{array}$ & $\begin{array}{l}\mathrm{AL}_{2} \mathrm{O}_{3} \text { nano- } \\
\text { material }(1-4 \%) \\
\text { in } \\
\text { pure liquid } \\
\text { water }\end{array}$ & $\begin{array}{l}\text { corrugated plate } \\
\text { heat exchanger } \\
470\end{array}$ & $\begin{array}{l}\text { The pressure } \\
\text { drop and pumping power } \\
\text { were increased with increase } \\
\text { in nanofluid concentration } \\
\text { and Reynolds number. }\end{array}$ \\
\hline $\begin{array}{l}\text { P. } \\
\text { Sivashanmugam } \\
\text { et al., } 2007\end{array}$ & $\begin{array}{l}\text { Twist ratio= } 1.95 \\
\text { to } 4.89 \text {, } \\
\text { Working Fluid - } \\
\text { Water }\end{array}$ & Not used & $\begin{array}{l}\text { helical screw- } \\
\text { tape inserts }\end{array}$ & $\begin{array}{l}\text { The heat transfer coefficient } \\
\text { increases with the twist ratio } \\
\text { and friction factor } \\
\text { also increases with the twist } \\
\text { ratio }\end{array}$ \\
\hline $\begin{array}{l}\text { Alpesh Mehta et } \\
\text { al. } 2007\end{array}$ & $\begin{array}{l}\text { Using } 6 \text {-NTU } \\
\text { rating numerical } \\
\text { method on turbo- } \\
\text { charged diesel } \\
\text { engine of type } \\
\text { TBD } 232 \mathrm{~V}-12 \\
\text { cross flow } \\
\text { compact heat } \\
\text { exchanger radiator } \\
\text { consisting of } 644 \\
\text { brass tubes and } \\
346 \text { copper } \\
\text { continuous fins }\end{array}$ & $\begin{array}{l}\mathrm{AL}_{2} \mathrm{O}_{3}+\text { water } \\
\text { nano fluids }\end{array}$ & Not used & $\begin{array}{l}\text { Increment in efficiency and } \\
\text { effectiveness } \\
\text { by using LMTD method and } \\
\text { NTU method } 12.5 \% \text { and } \\
16 \% \text { respectively. }\end{array}$ \\
\hline
\end{tabular}


International Journal of Trend in Scientific Research and Development (IJTSRD) ISSN: 2456-6470

\begin{tabular}{|c|c|c|c|c|}
\hline $\begin{array}{l}\text { Gregory J. } \\
\text { Zdaniuk et al. , } \\
2008\end{array}$ & $\begin{array}{l}\text { Helix angles }=25 \\
\& 48, \text { fin height to } \\
\text { diameter ratios } \\
0.0199 \& 0.0327 \\
\text { Re no. }=12,000- \\
60,000, \text { Working } \\
\text { Fluid = Water }\end{array}$ & Not used & $\begin{array}{l}\text { helically-finned } \\
\text { tubes }\end{array}$ & $\begin{array}{l}\text { Moreover, due to the gaps in } \\
\text { understanding of the flow in } \\
\text { spirally-finned tubes, more } \\
\text { research should be } \\
\text { performed on the influence } \\
\text { of geometric parameters on } \\
\text { flow patterns, especially in } \\
\text { the interfin region } \\
\text { Heat } \\
\text { transfer rate and friction } \\
\text { factor increase to } 1.67 \text { times } \\
\text { and } 6.76 \text { times. }\end{array}$ \\
\hline $\begin{array}{l}\text { N. Kannadasan } \\
\text { et al. } 2012\end{array}$ & $\begin{array}{l}\text { Dean No. } 1600- \\
4000, \text { Nanofluids } \\
\text { at } 0.1 \% \text { and } 0.2 \% \\
\text { by volume } \\
\text { concentrations }\end{array}$ & $\begin{array}{l}\mathrm{CuO} / \text { water } \\
\text { nanofluids }\end{array}$ & $\begin{array}{l}\text { Helically coiled } \\
\text { heat exchanger } \\
\text { held in } \\
\text { horizontal and } \\
\text { vertical positions }\end{array}$ & $\begin{array}{l}\text { Increment in Nusselt number } \\
\text { at } 0.1 \% \text { and } 0.2 \% \\
\mathrm{CuO} / \text { water nanofluid were } \\
\text { found } \\
\text { to be } 36 \% \text { and } 45 \% \\
\text { respectively compared with } \\
\text { water in horizontal position. } \\
\text { And increment in Nusselt } \\
\text { number at } 0.1 \% \text { and } \\
0.2 \% \mathrm{CuO} / \text { water nanofluid } \\
\text { were found to be } 37 \% \text { and } \\
49 \% \text { respectively compared } \\
\text { with water in vertical } \\
\text { position. }\end{array}$ \\
\hline $\begin{array}{l}\text { S. Senthilraja et } \\
\text { al. } 2013\end{array}$ & $\begin{array}{l}\text { Re . No.-2000- } \\
24000 \mathrm{CuO} / \text { water } \\
\text { by } \\
\text { volume } \\
\text { concentrations } 0.1 \\
\& 0.3 \text { vol. } \%\end{array}$ & $\begin{array}{l}\mathrm{CuO} / \text { water } \\
\text { nanofluids }\end{array}$ & $\begin{array}{l}\text { Not used } \\
\text { ent }\end{array}$ & $\begin{array}{l}\text { The enhancement of } \\
\text { nanofluid is } \\
\text { directly proportional to the } \\
\text { particle volume } \\
\text { concentration. Maximum } \\
18.46 \% \text { increased heat } \\
\text { transfer is found for } .3 \text { vol. } \% \\
\text { of nano particles. }\end{array}$ \\
\hline $\begin{array}{l}\text { H.A. Mintsa et al. } \\
2009\end{array}$ & $\begin{array}{l}\mathrm{h} / \mathrm{D}=0.01-0.05 \\
\mathrm{~h}=\mathrm{Rib} \text { width or } \\
\text { Height } \\
\mathrm{D}=\text { Tube } \\
\text { Diameter } \\
\text { Working Fluid- } \\
\text { Air }\end{array}$ & $\mathrm{Nc}$ & D:1 & $\begin{array}{l}\text { Rib inclination augments } \\
\text { heat transfer performance in } \\
\text { comparison to transverse } \\
\text { ribs and that the highest heat } \\
\text { transfer augmentation was } \\
\text { obtained with a rib } \\
\text { inclination somewhere } \\
\text { around } 60\end{array}$ \\
\hline $\begin{array}{l}\text { M.A. Khairul et } \\
\text { al. } 2011\end{array}$ & $\begin{array}{l}\text { concentration from } \\
0.50 \text { to } 1.50 \% \\
\text { compared to water }\end{array}$ & $\begin{array}{l}\text { Diff. metal } \\
\text { oxide }\end{array}$ & corrugated plate & $\begin{array}{l}\text { The } \\
\text { heat transfer coefficient of } \\
\mathrm{CuO} / \text { water nanofluids } \\
\text { increased about } 18.50 \text { to } \\
27.20 \% \text { with the } \\
\text { enhancement of } \\
\text { nanoparticles } \\
\text { volume concentration from } \\
0.50 \text { to } 1.50 \% \text { compared to } \\
\text { water. }\end{array}$ \\
\hline
\end{tabular}


International Journal of Trend in Scientific Research and Development (IJTSRD) ISSN: 2456-6470

\begin{tabular}{|c|c|c|c|c|}
\hline $\begin{array}{l}\text { P. } \\
\text { Sivashanmugam } \\
\text { et al., } 2007\end{array}$ & $\begin{array}{l}\text { Twist ratio= } 1.95 \\
\text { to } 4.89 \text {, } \\
\text { Working Fluid - } \\
\text { Water }\end{array}$ & Not used & $\begin{array}{l}\text { helical screw- } \\
\text { tape inserts }\end{array}$ & $\begin{array}{l}\text { The heat transfer coefficient } \\
\text { increases with the twist ratio } \\
\text { and friction factor } \\
\text { also increases with the twist } \\
\text { ratio }\end{array}$ \\
\hline $\begin{array}{l}\text { Heydar Maddah } \\
\text { et al. } 2010\end{array}$ & $\begin{array}{l}\text { GPR(geometric } \\
\text { progression ratio) } \\
\text { of } 2,1.5,1.2,1, \\
0.85,0.75 \text { and } \\
0.60, \\
\mathrm{w}=48 \mathrm{~mm} \\
\mathrm{~d}=.8 \mathrm{~mm} \\
\text { Reynolds number= } \\
5000 \text { to } 21,000\end{array}$ & $\begin{array}{l}\mathrm{Al}_{2} \mathrm{O}_{3} / \text { water } \\
\text { nanofluid }\end{array}$ & $\begin{array}{l}\text { modified } \\
\text { twisted tapes }\end{array}$ & $\begin{array}{l}\text { the experimental } \\
\text { data, utilization of RGPR } \\
\text { twists together with } \\
\text { nanofluids tends to increase } \\
\text { heat transfer and friction } \\
\text { factor } \\
\text { by } 12 \% \text { to } 52 \% \text { and } 5 \% \text { to } \\
28 \% \text { as compared with the } \\
\text { tube with typical twisted } \\
\text { tapes }(\mathrm{GPR}=1) \text { and } \\
\text { nanofluid }\end{array}$ \\
\hline
\end{tabular}

\section{CONCLUSIONS}

Understanding and improving heat transfer rate are the main concerns at different industries, including chemical processes, heating and cooling processes and micro-sized applications. Several techniques have been carried out to reduce operating cost. The most significant variables in reducing the size and cost of a heat transfer equipment's are heat transfer coefficient and pressure drop or flow resistance. The main concern for the equipment design is to minimize the flow resistance while enhancing the heat transfer coefficients. Therefore, it is vital to develop techniques to enhance the performance of heat exchangers. It has been commonly understood that the performance of heat exchangers can be improved by many augmentation techniques. Among them, utilizing nano fluids and passive augmentation techniques like inserting turbulence promoters are considered as the effective ones.

Choi was the first who suggested the addition of solid particles in nanometric size into a base fluid and reported enhancement of thermal conductivity compared to base fluid. Many studies have conducted to evaluate the heat transfer performance and flow characteristics of various nanofluids in both the laminar and the turbulent flow regimes. Results of these studies proved that the inclusion of nanoparticles improves the thermal conductivity compared to the conventional fluid and increases heat transfer rate with the nano particle concentration. Although lots of investigations manifested the thermal conductivity contribution toward the enhancement in the convective heat transfer coefficient of nano fluids.
Although numerous investigations have been conducted on the compound heat transfer augmentations, to our best knowledge, the combination of two techniques consisting of utilizing nanofluid and inserting coiled insert has not been reported. Therefore, the purpose of the present work is to study the combined effects of these two techniques. Heat transfer can also be enhanced by using nanofluid $(\mathrm{CuO}+$ pure water) equipped with coiled inserts $(\mathrm{p} / \mathrm{d}$ ratios are 0,2 and 4 ) in a 2 meter copper tube. Nanofluid increase the thermal conductivity of base fluid (pure water). These coiled inserts acts as a turbulence generator. The use of this generated turbulence is expected to create the tangential velocity to prolong residence time of the flow and to enhance the tangential and radial fluctuation, therefore leading to increase in heat transfer inside the test tube.

\section{REFERENCES}

1) Khwanchit Wongcharee, Smith Eiamsa-ard, Heat transfer enhancement by using $\mathrm{CuO} /$ water nanofluid in corrugated tube equipped with twisted tape. International Communications in Heat and Mass Transfer 39 (2012) 251-257

2) Heydar Maddah, Mostafa Alizadeh, Nahid Ghasemi, Sharifah Rafidah Wan Alwi, Experimental study of A12O3/water nanofluid turbulent heat transfer enhancement in the horizontal double pipes fitted with modified twisted tapes, International Journal of Heat and Mass Transfer 78 (2014) 1042-1054 
3) N. Kannadasan, K. Ramanathan, S. Suresh, Comparison of heat transfer and pressure drop in horizontal and vertical helically coiled heat exchanger with $\mathrm{CuO} /$ water based nano fluids, Experimental Thermal and Fluid Science 42 (2012) 64-70

4) A.E. Kabeel, T. Abou El Maaty , Y. El Samadony, The effect of using nano-particles on corrugated plate heat exchanger performance, Applied Thermal Engineering 52 (2013) 221e229

5) Mohammad Hemmat Esfe, Seyfolah Saedodin, Omid Mahian, Somchai Wongwises, Heat transfer characteristics and pressure drop of $\mathrm{COOH}-$ functionalized DWCNTs/water nanofluid in turbulent flow at low concentrations, International Journal of Heat and Mass Transfer 73 (2014) 186194.

6) A.A. Rabienataj Darzi, Mousa Farhadi , Kurosh Sedighi, Rouzbeh Shafaghat, Kaveh Zabihi, Experimental investigation of turbulent heat transfer and flow characteristics of $\mathrm{SiO} 2 /$ water nanofluid within helically corrugated tubes. International Communications in Heat and Mass Transfer 39 (2012) 1425-1434

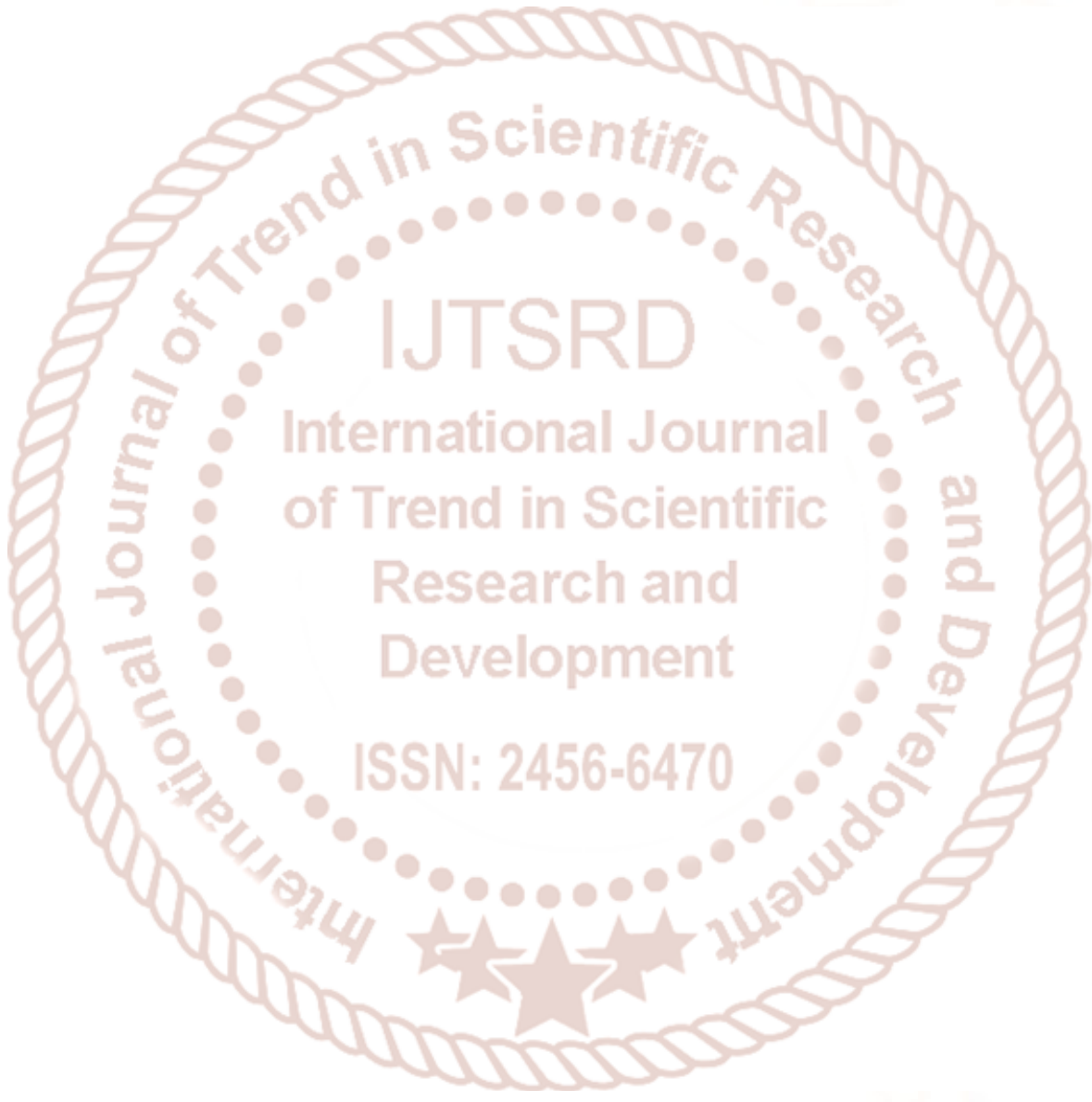

